\title{
Monetary Policy and Nigeria's Economy: An Impact Investigation
}

\author{
Micheal Chidiebere Ekwe ${ }^{1}$, Amah Kalu Ogbonnaya ${ }^{1} \&$ Cordelia Onyinyechi Omodero ${ }^{1}$ \\ ${ }^{1}$ College of Management Sciences, Micheal Okpara University of Agriculture Umudike, Abia State, Nigeria \\ Correspondence: Cordelia Onyinyechi Omodero, Department of Accounting, College of Management Sciences, \\ Micheal Okpara University of Agriculture Umudike, Abia State, Nigeria. E-mail: cordeliaomodero@yahoo.com
}

Received: September 11, 2017

Accepted: October 22, $2017 \quad$ Online Published: October 25, 2017

doi:10.5539/ijef.v9n11p218

URL: https://doi.org/10.5539/ijef.v9n11p218

\begin{abstract}
The major objective of this study is to empirically analyze the impact of monetary policy on the economy of Nigeria. To achieve this major objective, the study made use of broad money supply (M2) and credit to the private sector (CPS) as the independent variables explaining the dependent variable which is the Gross Domestic Product (GDP). The time series data employed cover the period of 1996 to 2016 and have been collected from the Central Bank of Nigeria Statistical Bulletin. The statistical tool used in this study is the multi regression and student t-test with the aid of statistical package for social sciences (SPSS) to analyze the impact of the individual explanatory variables on the economy. The result indicates that the monetary policy in Nigeria does not have significant impact on the economy. At 5\% level of significance, the broad money supply (M2) is $0.36>0.05$ while the CPS shows $0.22>0.05$. The result proves that the broad money supply has not been properly regulated and the bank lending rate to the private sectors so high that the economy has been adversely affected. The study therefore, recommends that the Central Bank of Nigeria should put every machinery in place to ensure that the monetary policy is geared towards economic growth through substantial reduction of bank lending rate to the private sector and proper regulation of broad money supply.
\end{abstract}

Keywords: monetary policy, broad money supply (m2), credit to the private sector, Gross Domestic Product (GDP), economy and Nigeria

\section{Introduction}

The focus of every country's monetary policy is to promote economic activities through money supply. Monetary policy as defined by CBN (2006), is the specific actions by the Central Bank to regulate the value, supply and cost of money in the economy with a view to achieving government's macroeconomic objectives. The money supply comprises the narrow money (M1) and the broad money (M2). Narrow Money (M1) is defined to include currency in circulation plus current account deposits with commercial banks. Broad Money measures the total volume of money supply in the economy which includes narrow money, currency outside Banks, demand deposits including foreign denominated deposits and quasi money (CBN, 2006). Monetary policy also determines the amount of credit available to the private sector. Credit to the private sector is the total amount of loans to businesses in Nigeria by Nigerian banks (Nairametrics, 2017). "Credit to the private sector has remained below the benchmark, which warrants policies that will enhance flow of credit to the private sector according to Central Bank of Nigeria" (Business Day Newspaper, 2016). The President, Lagos Chamber of Commerce and Industry (LCCI), Goodie Ibru lamented that the high lending rate by the CBN is squeezing potential private sector borrowers as a result there is a steady decline in credit to businesses. According to Mr. Ibru, "CBN lending rate is strangling the private sectors" (Premium Times, 2012). There ought to be an equilibrium between money supply and economic activities. However, money supply can be in excess when the amount of money in circulation is higher than the level of total output of the economy. If the level the economy can resourcefully utilize is below the money supply, it adversely affects the price stability which leads to inflation. This is where it becomes highly imperative for money supply to be regulated by the appropriate authority. In order to facilitate the attainment of price stability and to support the economic policy of the Federal Government in Nigeria, S.12 (1-5), CBN ACT of 2007 (Amended) allows this responsibility to rest on the CBN Monetary Policy Committee (MPC). The MPC comprises: the Governor of the Bank as Chairman; the four Deputy Governors of the Bank; two members of the Board of Directors of the Bank; three members appointed by the President and two members appointed by the Governor. As a matter of fact, money supply regulation does not call for policies that are capable of dwindling the economy through recession but should rather improve and 
effect economic growth. The study seeks to achieve two specific objectives. First, to establish the impact of the broad money (M2) on the economy of Nigeria. Secondly, to examine the influence of the credit to private sector on the Nigerian economy.

\section{Review of Related Literature}

Monetary policy theories and empirical studies by scholars are enormous with divergent views. The few selected for this study have been reviewed and their contributions highlighted in this section.

\subsection{Quantity Theory of Money}

The quantity theory of money has been adopted in this study. The quantity theory of money of American Economist Irving Fisher is a theory about the demand for money in an economy. It states that the general price level of goods and services is directly proportional to the money supply. This implies that money supply and price level in an economy are in direct proportion to one another. It shows that when there is a change in the supply of money, there is a proportional change in the price level and vice-versa. The theory assumes that the value of money, is determined by the amount of money available in an economy. That is, an increase in money supply results to a decrease in the value of money because when there is too much money in circulation there is a hike in the prices of goods and services. The purchasing power or the value of money decreases. The theory also assumes that the quantity of money, which is determined by outside forces, is the main influence of economic activity in a society. The theory is expressed as: $\mathrm{MV}=\mathrm{PT}$ (the Fisher equation). Where $\mathrm{M}=$ Money supply; $\mathrm{V}=$ Velocity of circulation (i.e., the number of times money changes hands); $\mathrm{P}=$ Average price level and $\mathrm{T}=$ Volume of transactions of goods and services. The theory assumes that V (Velocity of circulation) and $\mathrm{T}$ (Volume of transactions) are constant in the short run. It has been argued by the Keynesian Economists and Economists from the Monetarist School of Economics that the velocity of circulation depends on consumer and business spending impulses which cannot be constant (Heakal, 2017; TET, 2017). The criticism is that the velocity of money does not remain constant over time. Though the criticism, but it is established that the theory has been widely respected and accepted as a good monetary policy theory which helps to regulate money supply to avoid inflation and other adverse effect on the economy.

\subsection{Loanable Funds Theory}

The loanable funds theory of interest advocates that the demand and supply of loanable funds present in the capital market should determine the lending or interest rate. Therefore, keeping the same level of supply, an increase in the demand for loanable funds would lead to an increase in the interest rate and vice versa. "An increase in the supply of loanable funds would result in fall in the rate of interest. If both the demand and supply of the loanable funds change, the resultant interest rate would depend on the magnitude and direction of movement of the demand and supply of loanable funds. The demand for loanable funds is derived from the demand from the final goods generated from the use of capital that is financed by the loanable funds. The government also creates demand for loanable funds" (Bernake, 2002). In line with this study, this theory supports that bank lending rate should be determined by the forces of demand and supply for money. When demand for investing fund is high the bank lending rate can move in the same proportion while if it is low, it sends a signal that business is low, therefore the lending rate should reduce.

\subsection{Gross Domestic Product and Money Supply (GDP \& MSS)}

Onyeiwu (2012) used the ordinary least squares method (OLS) to investigate the impact of monetary policy on the Nigerian economy. The secondary data used ranged from 1981 to 2008 and were collected from the CBN Statistical Bulletin and National Bureau of Statistics. The study represented economic growth which is the dependent variable with GDP, inflation rate and balance of payment total. The result shows that money supply (M2) which is the independent variable exerts a significant positive impact $(0.00<0.05)$ on the GDP and balance of payment while on the inflation rate, a negative impact was revealed. It has been earlier revealed in the Fisher equation that an increase in money supply causes inflation and reduces the purchasing power. The negative effect of money supply on inflation rate could be a proof of the quantity theory of money by Irving Fisher. However, the result revealed a positive impact of M2 on GDP.

Udude (2014) employed the Augmented Dickey Fuller Unit Root Test, Johansen Co-integration Test and Vector Error Correction Mechanism (VECM) to empirically examine the impact of monetary policy on the growth of Nigerian economy between the periods of 1981 to 2012. The dependent variable used is the GDP while the independent variables were $\mathrm{M} 2$, interest rate, exchange rate and inflation rate. The result among others shows that the money supply impact is not statistically significant within the period covered by the study.

Abdulazeez (2016) investigated the impact of monetary policy on the economy of Nigeria and found a marginal 
impact of all the variables on the economic growth including the money supply. Nwoko, Ihemeje, and Anumadu (2016) tested the influence of money supply, average price, interest rate and labour forces on the Gross Domestic product using the statistical tool of multiple regression model for analysis. The data employed covered the period of 1990 to 2011. The findings among others indicate that money supply does not have influence on GDP. This result is not in agreement with the study of Onyeiwu (2012) which shows a significant positive impact of money supply on GDP, but is in consistent with the study of Udude (2014) which reveals an insignificant impact on GDP

\subsection{Gross Domestic Product and Credit to the Private Sectors (GDP \& CPS)}

Ngerebo-A (2016) carried out a study on monetary policy and inflation in Nigeria. The research employed a time series data covering a period of 1985 to 2012. Multiple regression was the statistical tool used with the aid of Software Package for Social Sciences (SPSS). The finding amongst others reveals that credit to private sector (CPS) is statistically significant in explaining the changes in inflation rate which serves as proxy for the economy. The recommendation is that credit to private sector should be properly guided and directed by the relevant authority (CBN) to avoid excess money in circulation that will lead to inflation.

Olowofeso, Adeleke, and Udoji (2015) used the Gregory and Hansen (1996) Co-integration test that accounted for structural breaks and endogeneity problems to investigate the impact of credit to private sector (CPS) on economic growth in Nigeria. The findings revealed that credit to private sector has a significant positive impact on GDP. The paper therefore, supports the continuing CBN effort to encourage the private sectors activities through gradual reduction of interest rate and by making the financial institutions a real sector friendly.

Modebe, Ugwuegbe, and Ugwuoke (2014) assessed the impact of bank credit on the growth of Nigerian economy using a co-integration approach. Time series data from CBN statistical bulletin covering the period of 1986 to 2012 were employed. The result indicates that the total bank credit to the private sector has a negative and insignificant impact on GDP at the short run. The study recommends that CBN should reduce the lending rate through adjustment of the monetary policy rate to enable private sectors businesses thrive and so far the economy will grow. This study confirms what Mr. Ibru lamented as earlier mentioned that the CBN lending rate is strangling the private sectors. Though the study of Olowofeso, Adeleke \& Udoji (2015) is in conflict with this result.

Were, Nzomoi, and Rutto (2012) examined the impact of credit to private sector (CPS) on economic performance (GDP) in Kenya using sectoral panel data. The empirical results show that CPS has significant and positive impact on sectoral GDP. Though, when labour is put under control, the impact reduces from 0.30 to 0.19 . However, despite the little impact, the findings are in consistent with the study of scholars like (Abu-Boder \& Abu-Qarn, 2008; Rajan \& Zingales, 1998).

Literature on the impact of monetary policy on economic growth is usually inconclusive. The Keynesians believe that monetary policy does not effectually impact on economic growth, while the Monetarists hold the view that changes in monetary policy affect economic growth. The various empirical studies reviewed give different results due to difference in the time periods studied and the statistical tools employed. However, this study focuses on the monetary policy impact on the economy of Nigeria. The GDP is used to represent the economy which is the dependent variable while the money supply (MSS i.e.M2) and the credit to the private sector (CPS) will be proxy for monetary policy which are the independent variables.

\section{Model Specification and Definition of Variables}

This study seeks to examine the impact of monetary policy on the economy of Nigeria for a period of 1996 to 2016. The time series data have been gathered from the CBN statistical bulletin. To achieve the objective of this study, the econometric model used is as follows:

$$
G D P=f(M S S, C P S)
$$

The explicit form of equation (1) above is represented as follows:

$$
G D P=\propto+\beta 1 M S S+\beta 2 C P S+\mu
$$

Where

GDP $=$ Gross Domestic Product

MSS $=$ Money Supply (M2)

CPS $=$ Credit to the Private Sector

$\beta(1-2)=$ Coefficient of independent variables

$\mu=$ the Error Term 


\section{Data Analysis and Interpretation of Findings}

The independent variables regressed against the dependent variable show the extent to which each of them influences the GDP. The researchers applied the statistical package of social sciences (SPSS) aid in the computation of the measurements of the multiple regressions for the study. The findings are outlined below:

Table 1. Model summary

\begin{tabular}{lc}
\hline Model & 1 \\
\hline R & .984 \\
R Square & .969 \\
Adjusted R Square & .965 \\
Std. Error of the Estimate & 6417.37038 \\
Durbin-Watson & 1.149 \\
\hline
\end{tabular}

Note. Predictors: (Constant\}. MSS, CPS; Dependent variable: GDP.

Source: Research findings (SPSS Result).

Table 1 above indicates the $\mathrm{R}$ and $\mathrm{R}^{2}$ values. The $\mathrm{R}$ value shows the simple correlation and the value is 0.984 (the " $R$ " Column) which implies that the percentage of correlation is high. The $R^{2}$ value (the " $R$ Square" Column) which is the coefficient of determination indicates how much of the total variation in the dependent variable (GDP), can be explained by the independent variables (MSS and CPS). In this case $96.9 \%$ can be explained which is very large. It can therefore be concluded that there are other factors not studied in this research which contributes $3.5 \%$ of the changes in the GDP in Nigeria. This can form a basis for further research to investigate these factors affecting $3.5 \%$ of the changes in the GDP in Nigeria.

Table 2. ANOVA

\begin{tabular}{lccc}
\hline Details & Regression & Residual & Total \\
\hline Model & 1 & & \\
Sum of squares & 23061232642.488 & 741287566.765 & 23802520209.253 \\
Degree of freedom & 2 & 18 & 20 \\
Mean square & 11530616321.244 & 41182642.598 & \\
F-ratio & 279.987 & & \\
Significant level & .000 & & \\
\hline
\end{tabular}

Source: Research Findings (SPSS Result).

Table 2 above indicates that the regression model significantly predicts the dependent variable (GDP). Taking a look at the "Regression" row and the "Sig" column, it shows the statistical significance of the regression model that was run. The p-value of $0.000<0.05$, which implies that the overall regression model is statistically significant (i.e. it is a good fit for the data).

Table 3. Coefficients

\begin{tabular}{lccc}
\hline Details & Constant & CPS & MSS \\
\hline Model & 1 & & 2.109 \\
B & 1304.620 & 2.744 & 2.248 \\
Std. Error & 2530.523 & 2.157 & .418 \\
Beta & & .567 & .938 \\
T-test & .516 & 1.272 & .361 \\
Significant level & .612 & .220 & \\
\hline
\end{tabular}

Dependent variable: GDP

Source: Research Findings (SPSS Result).

In order to determine the effect of monetary policy on the GDP using the two independent variable, the research conducted a multiple regression analysis.

The SPSS result on Table 3 shows the model equation can be presented thus:

$$
G D P=1304.620+2.744 C P S+2.109 M S S+\mu
$$

That means, if all other independent variables are taken at zero, a unit of CPS will lead to 2.744 unit increase in the GDP while a unit of MSS will lead to 2.109 unit increase in the GDP. However, the individual variables are not significant at $5 \%$ level of significant which means none of them has impact on the GDP. The p-value of CPS 
shows $0.22>0.05$; while MSS p-value indicates $0.36>0.05$. At $5 \%$ level of significance none of them is significant. The result of this study has proved the findings of (Udude, 2014; Modebe, Ugwuegbe, \& Ugwuoke, 2014; Abdulazeez, 2016) which revealed no impact of money supple and credit to private sectors on the GDP.

\section{Conclusion and Recommendation}

The study earlier stated that monetary policy is meant to grow the economy and not to cause recession. This is about the most recent review of this subject matter, though scholars have been expressing divergent views based on their findings, however the result of this study does not show that monetary policy of Nigeria is economic friendly. The high lending rate of banks in Nigeria is crippling private sectors which in turn adversely affect the economy. The money supply which is represented by the broad money has proved to be inadequate for economic activities to thrive. This study is therefore drawing the attention of the relevant authorities (CBN) and the policy makers to encourage private sectors by lowering the lending rate to enable them have enough funds to run their businesses. The infant industries should be encouraged especially those in the agricultural and manufacturing industries. This will help to increase export and commercial consumption which cause growth in the GDP.

\section{References}

Abdulazeez, M. N. (2016). Impact of Monetary Policy on the Economy of Nigeria. Pyrex Journal of Business and Finance Management Research, 2(10), 163-179.

Abu-Border, S., \& Abu-Qarn, A. S. (2008). Financial Development and Economic Growth: The Egyptian Experience. Journal of Policy Modeling, 30, 887-898. https://doi.org/10.1016/j.jpolmod.2007.02.001

Bernanke, B. S. (2002). Asset-price and Monetary Policy. New York 15 October, BIS Review 59/2002.

CBN. (2006). Monetary Policy Series. CBN/MPD/Series/01/2006. Central Bank of Nigeria, Monetary Policy Department.

Heakal, R. (2017). What is the Quantity Theory of Money? Investopedia. Retrieved August 21, 2017 from http://www.investopedia.com

Nairametrics. (2017). Data: Nigeria's Domestic Credit to Private Sector. Retrieved August 18, 2017 from https://nairametrics.com/

Ngerebo-A, T. A. (2016). Monetary policy and inflation in Nigeria. International Journal of Finance and Accounting, 5(2), 67-76.

Njoku, C. O., \& Dike, S. (2016). Monetary policy and economic stability in Nigeria: An empirical Analysis. International Journal of Research in Management, Science \& Technology, 4(1), 70-80.

Nwoko, N. M., Ihemeje, J. C., \& Anumadu, E. (2016). The impact of Monetary Policy on the Economic growth of Nigeria. An International Multi-disciplinary Journal, 10(3), 192-206. https://doi.org/10.4314/afrrev.v10i3.13

Oluwofeso, E. O., Adeleke, A. O., \& Udoji, A. O. (2015). Impact of private sector credit on Economic growth in Nigeria. CBN Journal of Applied Statistics, 6(2), 81-101.

Onyeiwu, C. (2012). Monetary policy and economic growth of Nigeria. Journal of Economics and Sustainable Development, 3(7), 62-70.

Premium Times. (2012). CBN's lending rate strangling private sector. Premium Times, Nigeria.

Rajan, R., \& Zingales, L. (1998). Financial Dependence and Growth. American Economic Review, 88, 559-586.

The Economic Times. (2017). Quantity Theory of Money. Retrieved August 21, 2017 from http://economictimes.indiatimes.com/

Udude, C. C. (2014). Monetary Policy and economic growth of Nigeria (1981-2012). Journal of Policy and Development Studies, 9(1), 234-247. https://doi.org/10.12816/0011194

Were, M., Nzomoi, J., \& Rutto, N. (2012). Assessing the impact of private sector credit on Economic performance: evidence from sectoral panel data for Kenya. International Journal of Economics and Finance, 4(3), 182-190. https://doi.org/10.5539/ijef.v4n3p182

\section{Copyrights}

Copyright for this article is retained by the author(s), with first publication rights granted to the journal.

This is an open-access article distributed under the terms and conditions of the Creative Commons Attribution license (http://creativecommons.org/licenses/by/4.0/). 